\title{
ORGANIC DYE DOPED MICROSTRUCTURES FOR OPTICALLY ACTIVE FUNCTIONAL DEVICES FABRICATED VIA TWO-PHOTON POLYMERIZATION TECHNIQUE
}

\author{
A. Žukauskas, M. Malinauskas, L. Kontenis, V. Purlys, D. Paipulas, M. Vengris, \\ and R. Gadonas \\ Department of Quantum Electronics and Laser Research Centre, Vilnius University, Sauletekio 10, LT-10223 Vilnius, \\ Lithuania \\ E-mail: mangirdas.malinauskas@ff.vu.lt
}

Received 12 October 2009; revised 2 March 2010; accepted 19 March 2010

\begin{abstract}
Femtosecond Laser Two-Photon Polymerization (LTPP) is a fabrication technique based on ultra-localized polymerization reaction initiated by nonlinear absorption of tightly focused light beam. It offers possibility to form three-dimensional (3D) micro- and nanostructures out of photopolymers. The point-by-point photostructuring allows fabrication of objects directly from Computer Aided Design (CAD) models and thereby the geometry of required structure can be changed flexibly. The smallest structural elements, also called voxels (volumetric pixels), of $200 \mathrm{~nm}$ lateral dimensions can be achieved with high repeatability. In this article, we present 3D microstructures fabricated out of hybrid zirconium-silicon containing hybrid sol-gel photopolymer ORMOSIL (SZ2080) doped with conventionally used fluorescent dyes: rhodamine 6G (R6G), fluorescein, DCM LC6500, and coumarin 152. The structural quality of the microobjects was investigated by Scanning Electron Microscopy (SEM). Interior of doped 3D micro- and nanostructures has been diagnosed with a custom made scanning fluorescence microscope. Additionally, fluorescing artificial scaffolds, which could be used for cell growth and cell tracking, were manufactured. Finally, the model of Distributed Feedback Dye Laser (DFBL) was successfully fabricated and this demonstrated the possibility to manufacture optically active elements from doped photopolymers.
\end{abstract}

Keywords: direct laser writing, doped polymers, 3D fabrication, distributed feedback dye laser

PACS: 42.70.Jk, 87.85.jj, 81.07.Pr

\section{Introduction}

Continuously growing interest in novel LaboratoryOn-a-Chip (LOC) systems and downsizing the dimensions of existing devices are the driving forces for development of the Direct Laser Writing (DLW) techniques, enabling fabrication of 3D structures with nanometre resolution. One of currently emerging DLW technologies for 3D nanofabrication is Laser Two-Photon Polymerization (LTPP) [1-4]. It is based on the localized polymerization reaction in the bulk of photoresist (prepolymer) initiated by two-photon absorption of femtosecond light pulses. Polymerization process is initiated by radicals formed from photoiniator molecules after two-photon excitation. This is followed by chemical chain reaction in which radicalized monomers or oligomers combine with new monomers until two radicalized polymer chains meet with each other and end the chain reaction [5]. As a result, the pre-polymer is solidified in the volume where concentration of gener- ated radicals is above the required threshold concentration for the irreversible polymerization leading to material solidification. Since the reaction is induced by two-photon absorption, photomodification is tightly localized in the volume of the focused laser beam. Due to nonlinear character of absorption as well as radical concentration threshold (minimum) required for stable polymer chain formation, the achieved fabrication resolution by LTPP can be below the diffraction limit [6]. Though the main attractive features of the LTPP are explored in detail in the reference papers [7,8], possibility to fabricate doped polymer structures by DLW is still important issue to be examined. For the fabrication of functional devices, doping of polymers with various active dopant molecules or nanoparticles could be essential in order to ensure required function relevant to application. Organic dye molecules could be an example of dopants providing fluorescence and lasing ability of the fabricated microstructures. Wide range 
of dye molecules with different properties is available in the optical region from UV (Ultra-Violet) to NIR (Near Infra-Red) wavelengths [9]. When introduced into polymer structures, these dopants could serve as fluorescence markers in order to examine the interior of 3D devices using modern laser scanning fluorescence microscopy methods enabling optical sectioning. Internal diagnosis of fabricated structures is of great importance for the development of LTPP technology towards high accuracy true 3D fabrication [10]. In biomedical applications, fluorescing scaffolds for cell culture growth would enable better imaging of proliferating cell cultures $[11,12]$. Finally, tunable light sources integrated in LOC microsystems are attractive for novel sensor concepts. One of such photonic device for compact integrated light sources is DFBL [13], with cavity based on light confinement in a Bragg's grating. Such microlasers are particularly suitable as LOC components because of possibility to integrate them with other functional polymer components. Moreover, in order for the lasers to be used in sensor systems a large Free Spectral Range (FSR) of the cavity is required, which often implies having subwavelength features [14].

In this paper, we present experimental results on fabrication of organic dye doped zirconium-silicon containing hybrid sol-gel polymer microstructures by using direct writing LTPP technique.

\section{Experimental set-up and materials}

The experimental set-up of the femtosecond laser microfabrication system used for LTPP is shown in Fig. 1. As an irradiation source, a mode-locked Ti:Sapphire (Super Spitfire, Spectra Physics) laser emitting 80 fs pulses at repetition rate of $80 \mathrm{MHz}$ and having a central wavelength fixed at $800 \mathrm{~nm}$ was used. The sample was fixed on three axis piezo nanopositioning stage (Nanocube, Physik Instrumente $\mathrm{GmbH}$ ) having step resolution of $1 \mathrm{~nm}$ and travel range reaching $100 \mu \mathrm{m}$ in three perpendicular $(X Y Z)$ directions. Additionally, the stage was mounted on three micrometre-step motor stages (Standa Ltd) to increase the overall processing area. $100 \times(\mathrm{NA}=1.4)$ immersion oil microscope objective (SplanApo, Olympus Corp.) was used to tightly focus the laser beam into the sample. An inverted transmission microscope formed by red light LED source, objective, and additional lenses together with CMOS camera (mvBlueFOXM102G, Matrix Vision $\mathrm{GmbH}$ ) was used for real time monitoring of the fabrication process. Set-up for real time monitoring of manufacturing process ensured easy anchoring of the fabricated structures to the glass substrate, thus tracking the waviness of substrate surface and deviations from horizontal positioning. The laser intensity was attenuated by using $\lambda / 2$ waveplate combined with polarizer $P$ and the exposure time was adjusted using home-made shutter $S$ with response time of $5 \mathrm{~ms}$. The fabrication process was controlled by custom-made software " $3 \mathrm{D}$

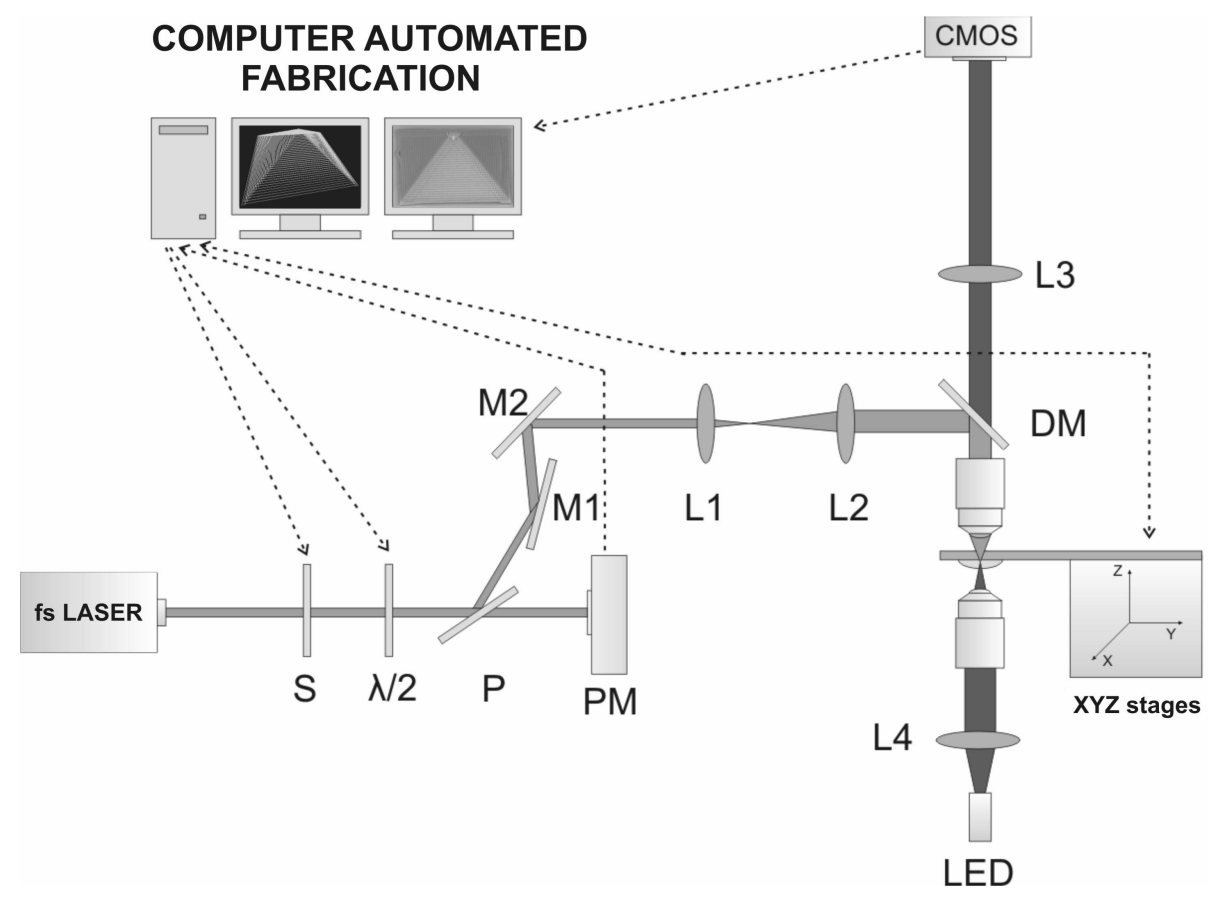

Fig. 1. LTPP microfabrication set-up. 


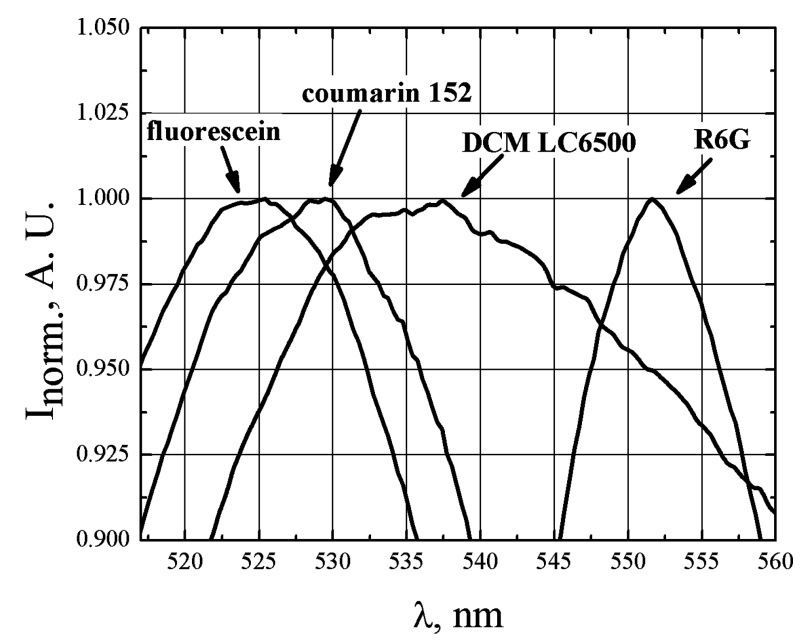

Fig. 2. Normalized emission spectra of ORMOSIL doped with fluorescent dyes measured at $409 \mathrm{~nm}$ excitation.

Poli” designed for 3D fabrication. It provides possibility to import and fabricate structures from stereolithography CAD files or to design and fabricate desired $3 \mathrm{D}$ features by the software directly.

In our experiments we used negative hybrid solgel polymer ORMOSIL (ORganic MOdified SILica, FORTH) mixed with 2 wt. \% Michler's ketone (4,4'-Bis(dimethylamino)benzophenone, Sigma-Aldrich $\mathrm{GmbH}$ ) as the photoiniator. The absorption peak of the photoiniator is around $400 \mathrm{~nm}$, so it is well suitable for two-photon excitation by $800 \mathrm{~nm}$ wavelength.
ORMOSIL has a set of attractive properties such as low shrinkage (under development of the material), optical transparency in the VIS and NIR, chemical and thermal stability, and high structural rigidity [15]. Samples for the fabrication were prepared by drop-casting organic dye doped photoresist on a glass substrate and drying on a hotplate at $90^{\circ} \mathrm{C}$ for 1 hour. After laser processing samples were treated with developer 4-methyl-2pentanone (Acros Organics b. v. b. a.) in order to wash out the unexposed photoresist. As light exposed photoresist undergoes polymerization and becomes insoluble in the developer, polymerized features sustain during development process. In this way, the free-standing structures on a glass substrate were obtained.

Organic dyes used as dopants (see Table 1) were R6G (Molecular Probes Inc), fluorescein (Acros Organics b. v. b.a.), DCM LC6500 (Lambda Physik AG), and coumarin 152 (Sigma-Aldrich $\mathrm{GmbH}$ ). For doping of the photoresist, dyes were dissolved in isopropanol (Riedel-de Haen AG), and then the solution of a dye was mixed with ORMOSIL. The dopant concentration has been varied from 0.01 up to 0.05 wt. $\%$. The highest used concentration was limited by the dye solubility. If the dyes were not completely dissolved, microexplosions occurred and bubbles appeared in photopolymer during fabrication process. R6G and fluorescein have been selected for fabrication experiments as two differ-

Table 1. Properties of fluorescent dyes in ethanol $\left({ }^{*}\right.$ quantum yield in methanol).

Fluorescent dye Absorption peak, $\mathrm{nm}$ Emission peak, $\mathrm{nm}$ Quantum yield


ent dopants due to the high fluorescence quantum yield and emission spectra differences, given in Fig. 2.

\section{Results}

SEM image of 3D pyramid fabricated out of ORMOSIL doped with R6G up to 0.05 wt. \% is shown in Fig. 3(a). The pyramid is fabricated as hollow woodpile-like structure in which every layer starting from the base consists of two sets of four densely packed parallel rods at opposite sides of the square layer of the pyramid. In every adjacent layer, sets of rods are shifted to the centre of the pyramid and rotated by 90 degrees relative to the previous below lying layer. Thus, the resulting structure is hollow square pyramid, with height and base length of 30 and $65 \mu \mathrm{m}$ respectively. As seen from the SEM image, quality of the fabricated structure is good and no negative influence of dopant entrapped in the polymer has been detected. Under illumination by blue-green light the fabricated feature shows bright fluorescence with spectral features characteristic of the dopant R6G. It allows usage of the confocal fluorescence microscopy methods in order to examine the interior of the pyramid by optical sectioning. Fluorescence imaging was carried out by using conventional custom made confocal microscope. Femtosecond excitation pulses at $409 \mathrm{~nm}$ wavelength were focused by $50 \times(\mathrm{NA}=0.8)$ objective lens inside the pyramid. Emitted fluorescence was collected by the same lens and detected through dichroic mirror and confocal aperture of $60 \mu \mathrm{m}$ diameter. Figure 3(b) presents the result of fluorescence imaging of the interior of doped hollow pyramid. Optical sectioning was carried out layerby-layer from the base of the pyramid to the particular plane (Fig. 3(a)). The confocal section of the pyramid few woodpile layers below apex shows clearly resolvable rods forming opposite faces of the pyramid at the particular height. Though SEM imaging provides information on rather regular structure of the outside of the pyramid while fluorescence microscopy reveal that internal surfaces of the pyramid faces are covered with irregular structures probably formed during development procedure and drying of the rinsing solvent (Fig. 3(b)). Thus, our results demonstrate not only possibility but also the importance of examining the interior of the 3D structures fabricated by LTPP technique. We demonstrate that doping of the materials used for fabrication by LTPP with fluorescence marker molecules does not decrease the quality of the fabricated structures. However, it enables study of the interior of 3D structures by scanning microscopy techniques with optical sectioning capabilities such as confocal or nonlinear fluorescence microscopies.

The possibility to fabricate structures consisting of two or more materials having different mechanical and / or optical properties on the same substrate could offer the way to create "smart" microstructures. These structures act as a pre-designed micromechanism which is affected by changes in environmental conditions (e. g. actuator) [16]. To test this idea, we fabricated twocomponent grating out of ORMOSIL doped with R6G and fluorescein up to $0.05 \mathrm{wt} \%$. The grating was fabricated in successive manner using standard sample preparation, fabrication, and development procedures for every doped component. Firstly, horizontal lines were fabricated out of ORMOSIL doped with R6G and then unexposed photopolymer was washed away. Secondly, fluorescein doped ORMOSIL was drop-casted on free-standing horizontal lines and vertical lines were formed. The period of the grating is $5 \mu \mathrm{m}$. Fluorescence imaging (wavelength $800 \mathrm{~nm}$, objective $8 \times$ $(\mathrm{NA}=0.5))$ results are presented in Fig. 4. As emission spectra of R6G and fluorescein are partially overlapping (Fig. 2), better spectral separation of differ-

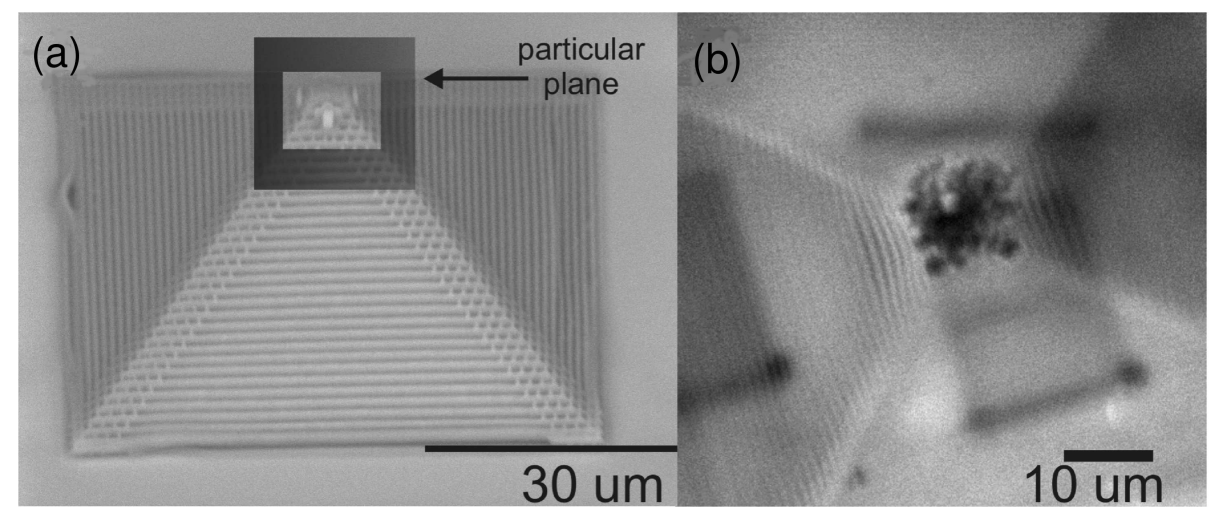

Fig. 3. (a) SEM and (b) fluorescence microscope images of 3D hollow pyramid fabricated out of ORMOSIL doped with R6G. The average laser power and sample translation speed used for fabrication were $23 \mathrm{~mW}$ and $50 \mu \mathrm{m} / \mathrm{s}$, respectively. 


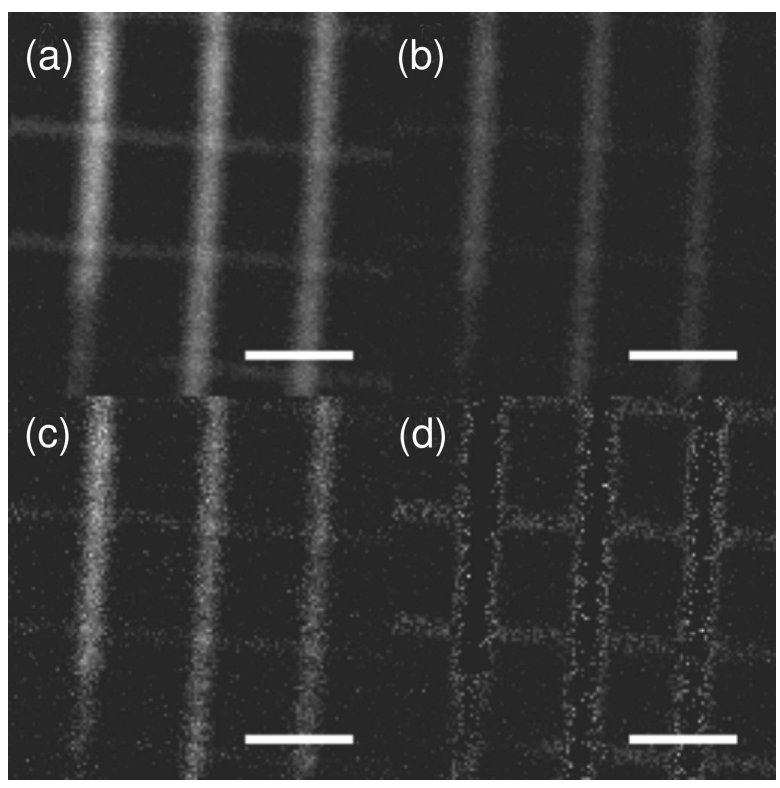

Fig. 4. Scanning fluorescence microscopy images of twocomponent grating fabricated out of ORMOSIL doped with fluorescein (vertical lines) and R6G (horizontal lines). (a) and (b) are raw images taken through 520 and $500 \mathrm{~nm}$ bandpass filters respectively. (c) and (d) are spectral separation of grating components from calculated distribution of rhodamine $6 \mathrm{G}$ and fluorescein concentration using linear regression analysis. Scale bars are $5 \mu \mathrm{m}$.

ent components of the grating was achieved by narrow bandpass filters (520 and $500 \mathrm{~nm}$, spectral bandwidth $10 \mathrm{~nm}$ FWHM) in front of the detector. Hence, separation of the grating components was not complete due to spectral overlap of the fluorescence emissions, horizontal grating lines are well resolved in the raw fluorescence image detected through $520 \mathrm{~nm}$ bandpass filter (Fig. 4(a)). Only the fluorescein doped vertical lines of the grating are present in the image taken through $500 \mathrm{~nm}$ filter (Fig. 4(b)). However, concentration distributions of dopants calculated from the raw images (Fig. 4(c, d)) reveal the presence of fluorescein in R6G doped horizontal line component of the grating as well as accumulation of R6G at the edges of vertical lines doped with fluorescein. This effect occurred due to extraction of dopants into rinsing solvent during second development procedure. Drying of the solvent results in accumulation of dopants at the edges where lines are attached to the glass substrate.

Structures fabricated by LTPP out of biocompatible polymers are supposed to serve as scaffolds for stem cell growth in regenerative medicine [17]. Marking scaffold with fluorescent dyes helps to trace cell proliferation in it as the structure is highly fluorescent upon investigation [11]. Figure 5 represents one of possible doped scaffold models for cell growth fabricated over relatively large area $\left(1 \times 1 \mathrm{~mm}^{2}\right)$. The dimension of one

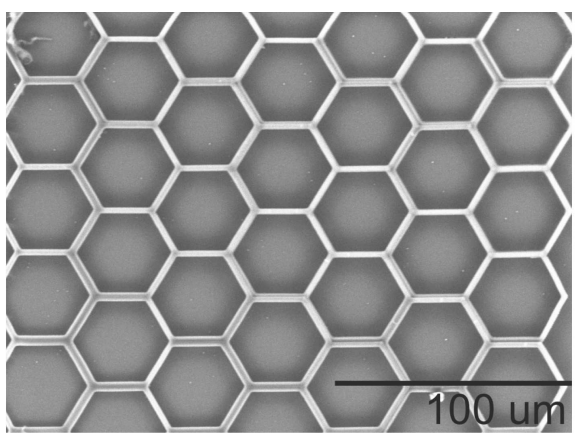

Fig. 5. SEM image of scaffold fabricated out of ORMOSIL doped with fluorescein. The average laser power and sample translation speed used for fabrication were $24 \mathrm{~mW}$ and $100 \mu \mathrm{m} / \mathrm{s}$ respectively.

honeycomb line is $20 \mu \mathrm{m}$. Recently, tested fluorescing scaffolds in preliminary cell growth experiments enable more detail observation of growth process using fluorescence microscopy methods.

Finally, one of the ultimate goals of doping polymer nanostructures with highly fluorescent molecules is to open the way for constructing optically active devices such as microlasers which would exploit the new possibilities of nanostructuring technologies of the lasing materials. One of the challenges is to produce microlasers such as DFBL [18]. An example of DFBL resonator model fabricated out of ORMOSIL doped with R6G with linewidth of $280 \mathrm{~nm}$ and period of $850 \mathrm{~nm}$ is shown in Fig. 6. Such lasing microstructures are supposed to be advantageous because of their compact size, low power consumption, and easy integration into more complex LOCs fabricated by using the same technological approach. The optical resonator is based on Bragg's grating structure with introduced phase shift of a $\pi / 2$ in the middle of resonator in order to obtain a single resonance for each Bragg's reflection. The grating parameters were calculated to satisfy the Bragg's condition

$$
m \lambda_{m}=2 \Lambda_{\mathrm{op}}
$$

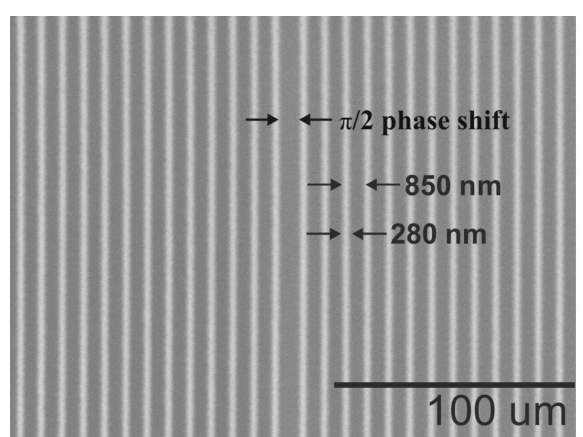

Fig. 6. SEM image of distributed feedback dye laser resonator model fabricated out of ORMOSIL doped with rhodamine 6G. The average power of laser and sample translation speed used for fabrication were $6 \mathrm{~mW}$ and $30 \mu \mathrm{m} / \mathrm{s}$, respectively. 
where $m=1,2,3, \ldots$ is the reflection order, $\lambda_{m}$ is the wavelength, and $\Lambda_{\text {op }}$ is the optical path length of one grating period [18]. Estimated optical path and linewidth for the third order reflection is 846 and $282 \mathrm{~nm}$ respectively. In order to test lasing ability of the DFBL model, the fabricated structure was sidepumped by frequency doubled radiation of Q-switched $\mathrm{Nd}$ :LSB microchip laser $(531 \mathrm{~nm}, 0.5 \mathrm{~ns}$ pulse duration at $5 \mathrm{kHz}$ repetition rate, Standa Ltd). Fluorescence of the structure was analysed with high resolution spectrometer (HR2000, Ocean Optics Inc.) expecting the spectral narrowing of the fluorescence at the higher optical pump intensity than threshold required to initiate lasing. We noticed continuous and instant bleaching of the fluorescent dye when the resonator was pumped with pulses having energies $E_{\mathrm{p}}=0.3 \mu \mathrm{J}$ and $E_{\mathrm{p}}=$ $0.932 \mu \mathrm{J}$, respectively. However, such energies were required for fluorescence detection and were not sufficient to initiate lasing. This implies that limited concentration [19] and photostability of dopant molecules is one of the main obstacles to get lasing out of polymer microstructures. Possible solution for this problem could be encapsulation of fluorescent dye's molecules into dendritic macromolecules (dendrimers) increasing organic dyes' concentration several tens of times [9] and making them less affected by reactive species such as radicals and singlet oxygen.

\section{Conclusions}

We have shown that doping of ORMOSIL with fluorescent dyes (R6G, fluorescein, DCM LC6500, and coumarin 152) up to $0.05 \mathrm{wt} \%$ does not significantly reduce photostructuring capabilities like structuring spatial resolution and dynamic fabrication window (the range between fabrication threshold power $P_{\text {th }}$ and optical damage power $P_{\mathrm{d}}$ ) of LTPP technology. Doped 3D micro- and nanostructures were successfully fabricated out of ORMOSIL. We demonstrate that doping with fluorescent dyes enables diagnosis of internal structure of fabricated 3D features by the means of fluorescence microscopy techniques. Doped artificial scaffolds for cell growth were fabricated facilitating observation of cell proliferation. Finally, DFBL laser model was fabricated from ORMOSIL doped with R6G. Low concentration and photostability of the dye in polymer matrix still remains the main problem to be solved in order to get functioning microdevice.

\section{Acknowledgements}

This work is supported by the Lithuania State Science and Studies Foundation Grant B09/08 (Laser Microprocessing with High Repetition Femtosecond Pulses - Femtoprocessing). Authors would like to thank colleagues from FORTH (Foundation of Research and Technology Hellas, bmm @ iesl.forth.gr) for providing zirconium containing hybrid sol-gel photosensitive material ORMOSIL (SZ2080). Lastly, authors acknowledge Dr. A.P. Žindulis (Vilnius University) for gold sputtering polymeric samples.

\section{References}

[1] S. Maruo, O. Nakamura, and S. Kawata, Threedimensional microfabrication with two-photonabsorbed photopolymerization, Opt. Lett. 22, 132-134 (1997).

[2] M. Miwa, S. Juodkazis, T. Kawakami, S. Matsuo, and H. Misawa, Femtosecond two-photon stereolithography, Appl. Phys. A 73, 561-566 (2001).

[3] J. Serbin, A. Egbert, A. Ostendorf, B.N. Chichkov, R. Houbertz, G. Domann, J. Schulz, C. Cronauer, L. Frohlich, and M. Popall, Femtosecond laser-induced two-photon polymerization of inorganic-organic hybrid materials for applications in photonics, Opt. Lett. 28(5), 301-303 (2003).

[4] S.-H. Park, D.-Y. Yang, and K.-S. Lee, Twophoton stereolithography for realizing ultraprecise three-dimensional nano/microdevices, Laser \& Photon. Rev. 3(1-2), 1-11 (2009).

[5] I. Wang, M. Bouriau, and P.L. Baldeck, Threedimensional microfabrication by two-photon-initiated polymerization with a low-cost microlaser, Opt. Lett. 27(15), 1348-1350 (2002).

[6] X.Z. Dong, Z.S. Zhao, and X.M. Duan, Improving spatial resolution and reducing aspect ratio in multiphoton polymerization nanofabrication, Appl. Phys. Lett. 92(9), 091113 (2008).

[7] S. Wu, J. Serbin, and M. Gu, Two-photon polymerization for three-dimensional micro-fabrication, J. Photochem. Photobiol. A 181, 1-11 (2006).

[8] M. Malinauskas, H. Gilbergs, V. Purlys, A. Žukauskas, M. Rutkauskas, and R. Gadonas, Femtosecond laserinduced two-photon photopolymerization for structuring of micro-optical and photonic devices, Proc. SPIE 7366, 7366-22 (2009).

[9] S. Yokoyama, T. Nakahama, H. Miki, and S. Mashiko, Two-photon-induced polymerization in a laser gain medium for optical microstructure, Appl. Phys. Lett. 82(19), 3221-3223 (2003).

[10] H.-B. Sun, T. Tanaka, K. Takada, and S. Kawata, Two-photon photopolymerization and diagnosis of 
three-dimensional microstructures containing fluorescent dyes, Appl. Phys. Lett. 79(10), 1411-1413 (2001).

[11] S. Constantino, K.G. Heinze, O.E. Martinez, P. Koninck, and P.W. Wiseman, Two-photon fluorescent microlithography for live-cell imaging, Microsc. Res. Tech. 68, 272-276 (2005).

[12] S. Schlie, A. Ngezahayo, A. Ovsianikov, T. Fabian, H.A. Kolb, H. Haferkamp, and B.N. Chichkov, Threedimensional cell growth on structures fabricated from ORMOCER by two-photon polymerization technique, J. Biomater. Appl. 22(3), 275-287 (2007).

[13] T. Woggon, T. Kleiner, M. Punke, and U. Lemmer, Nanostructuring of organic-inorganic hybrid materials for distributed feedback laser resonators by twophoton polymerization, Opt. Express 17(4), 2500-2507 (2009).

[14] M.B. Christiansen, M. Scholer, and A. Kristensen, Integration of active and passive polymer optics, Opt. Express 15(7), 3931-3939 (2007).

[15] A. Ovsianikov, S.Z. Xiao, M. Farsari, M. Vamvakaki, C. Fotakis, and B.N. Chichkov, Shrinkage of microstructures produced by two-photon polymerization of Zr-based hybrid photosensitive materials, Opt. Express 17(4), 2143-2148 (2009).

[16] T. Baldacchini, M. Zimmerley, E.O. Potma, and R. Zadoyan, Chemical mapping of three-dimensional microstructures fabricated by two-photon polymerization using CARS microscopy, Proc. SPIE 7201, 72010Q (2009).

[17] M. Malinauskas, P. Danilevičius, D. Baltriukienè, M. Rutkauskas, V. Chorosajev, Ž. Kairytè, G. Bičkauskaitè, A. Žukauskas, V. Purlys, D. Paipulas, V. Bukelskienè, and R. Gadonas, 3D artificial polymer scaffolds for regenerative medicine fabricated by femtosecond laser (submitted to Lithuanian J. Phys. 2010).

[18] M. Gersborg-Hansen and A. Kristensen, Tunability of optofluidic distributed feedback dye laser, Opt. Express 15(1), 137-142 (2006).

[19] C.R. Mendonca, D.S. Correa, M. Marlow, T. Voss, P. Tayalia, and E. Mazur, Three-dimensional fabrication of optically active microstructures containing an electroluminescent polymer, Appl. Phys. Lett. 95, 113309 (2009).

\title{
OPTIŠKAI AKTYVIŲ FUNKCINIŲ MIKRODARINIŲ FORMAVIMAS DVIFOTONĖS POLIMERIZACIJOS BŪDU IŠ POLIMERŲ SU ORGANINIŨ DAŽŲ PRIEMAIŠA
}

\author{
A. Žukauskas, M. Malinauskas, L. Kontenis, V. Purlys, D. Paipulas, M. Vengris, R. Gadonas \\ Vilniaus universitetas, Vilnius, Lietuva
}

\section{Santrauka}

Eksperimentiškai parodyta, kad lazerinès dvifotonès fotopolimerizacijos (LDFP) būdu galima formuoti optiškai aktyvias funkcines mikro- ir nanostruktūras, kuriu atkartojama skyra siekia iki $200 \mathrm{~nm}$. I ORMOSIL (SZ2080) fotopolimerą buvo įmaišoma įvairių organiniu dažų (rodamino 6G, fluoresceino, DCM LC6500 ir kumarino 152) iki 0,05\% koncentracijos, nepaveikiant mikrodarinių formavimo kokybès. Fluorescencinès skenavimo mikroskopi- jos metodu charakterizuoti dariniai, nustatyta jų vidinè sandara ir parodyta, kad organiniai dažai išlieka aktyvūs po darinių suformavimo LDFP metodu. Pademonstruota galimybè taikyti dirbtinius skeletus su organinių dažų priemaiša ląstelių proliferacijos eksperimentams. Suformuotas paskirstyto grižtamojo ryšio dažų mikrolazerio modelis. Nurodytos priežastys (maža organinių dažų koncentracija ir jų stabilumas polimerinejje matricoje), ribojančios šio elemento funkcionavimą, pateikti galimi to sprendimo būdai. 